\title{
A Stimulus Paradigm Inducing Long-term Desensitization of AMPA Receptors Evokes a Specific Increase in BDNF mRNA in Cerebellar Slices
}

Michisuke Yuzaki, ${ }^{1,3}$ Teiichi Furuichi, ${ }^{2}$ Katsuhiko Mikoshiba, ${ }^{2}$ and

Yasuo Kagawa ${ }^{1}$

${ }^{1}$ Department of Biochemistry

Jichi Medical School

Minamikawachi-machi

Tochigi 329-04, Japan

${ }^{2}$ Department of Neurobiology

Institute of Medical Science

University of Tokyo

Shirokanedai, Minato-ku

Tokyo 108, Japan

\begin{abstract}
Long-term desensitization of AMPA receptors (LTDA) is a core mechanism of long-term depression, a model of motor learning in the cerebellum. In this study we investigated the expression of neurotrophic factor genes after induction of LTDA in cultured cerebellar slices. LTDA was induced by application of quisqualate and monitored as a population response with a wedge recording technique. The levels of mRNA were quantified by reverse transcription followed by polymerase chain reaction. Quisqualate, at a dose and duration that reliably induced LTDA, elicited a significant and specific increase in BDNF mRNA with a peak at four hours after the application. By cell fractionation, the major source of BDNF mRNA increase was found to be in granule cells. In addition, a small but significant increase of transcripts with specific exon usage was observed in a Purkinje cell fraction. These results indicate that BDNF may be coinduced with LTDA and suggest that the slow and sustained
\end{abstract}

${ }^{3}$ Present address: Roche Institute of Molecular Biology, Nutley, New Jersey 07110. increase of BDNF mRNA might play a role in later phases of synaptic plasticity in the cerebellum.

\section{Introduction}

Maintenance of long-term memory is reported to require protein and mRNA syntheses, whereas induction of long-term memory, in some models of synaptic plasticity (Montarolo et al. 1986; Teyler and DiScenna 1987), does not. Several genes have been identified that are coinduced in longterm sensitization, a model of Aplysia learning (Kennedy et al. 1992; Mayford et al. 1992), and in long-term potentiation (LTP), a model of memory in the cerebral cortex and hippocampus of mammals (Wisden et al. 1990; Patterson et al. 1992). This suggests that neural activity induced by learning generally initiates a cascade of gene expression, but it is not clear whether these genes are necessary and sufficient for the long-lasting synaptic modification. To answer this question clearly, ablation or suppression of specific gene expression will be of great help, but for that purpose candidate genes coinduced in long-lasting memory models must be identified first. Little is known, however, about gene expression in long-term depression (LTD), a model of motor learning in the cerebellum.

LEARNING \& MEMORY 1:230-242 @ 1994 by Cold Spring Harbor Laboratory Press ISSN1072-0502/94 \$5.00

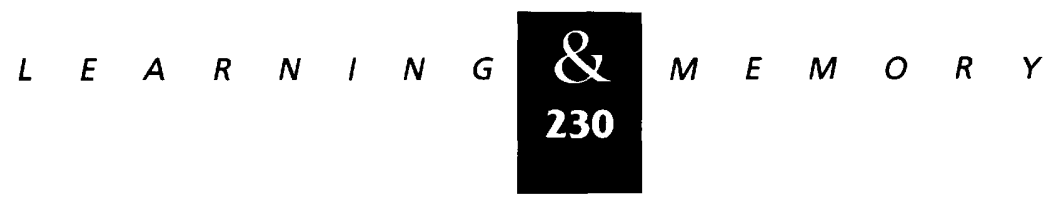


LTD is a persistent depression of transmission efficacy at synapses between parallel fibers and Purkinje cells induced by conjunctive stimulation of parallel and climbing fibers (Ito 1989). Electrophysiological studies have shown that persistently reduced sensitivity of the $\alpha$-amino-3-hydroxy-5. methyl-4-isoxazolone propionate (AMPA) type of glutamate receptor in Purkinje cells is the basic mechanism of LTD (Ito 1989; Linden and Connor 1991; Hémart et al. 1994), which we refer to as long-term desensitization of AMPA receptor (LTDA). One of the main reasons why little is yet known at the gene level about cerebellar LTD has been the difficulty in inducing, and recording LTD in large numbers of cells. LTD is difficult to detect with mass field potentials and thus induction of LTD by electrical stimulation was initially restricted to limited populations of cells (Ito 1989). Recently, however, recording from a population of Purkinje cells has become possible. Using a grease gap method in cerebellar slices trimmed to a wedge shape (wedge recording), Ito and Karachot $(1989,1990,1992)$ have shown LTDA, which lasts up to $13 \mathrm{hr}$, in a population of Purkinje cells. It has also been found that conjoint application of the metabotropic glutamate receptor (mGluR) agonist ( \pm )-1-aminocyclopentane-trans-1,3-dicarboxylic acid (trans-ACPD) and AMPA, or application of quisqualate alone, which activates both mGluR and AMPA receptors, can induce LTDA (Ito and Karachot 1989; Linden et al. 1991). The model of LTDA induced by pharmacological stimulus and monitored by wedge recording has a great advantage in the stability of recording and the number of neurons sampled, which are essential for the molecular biological study.

As a first step toward understanding the regulation of gene expression in cerebellar LTD, we adopted the quisqualate-induced LTDA model in cerebellar slices with monitoring by wedge recording. In this study we focused on the changes in the expressions of neurotrophic factors because they are necessary for the normal development and maintenance of neural functions (Otten et al. 1980; Diamond et al. 1987; Kalman et al. 1990; Nawa et al. 1993). Their expression in forebrain, mostly in the hippocampus, has also been shown to be increased by a variety of stimuli (Gall and Isackson 1989; Zafra et al. 1990; Ernfors et al. 1991; Isackson et al. 1991; Lu et al. 1991; Lindvall et al. 1992), including LTP (Patterson et al. 1992; Castrén, et al. 1993). Quantification of neurotrophin mRNAs in the cerebellum demonstrated that brain-derived neurotrophic factor (BDNF) mRNA was specifically induced by LTDA-evoking stimulation.

\section{Materials and Methods}

\section{SLICE CULTURE}

Cerebellar slices were cultured as described by Stoppini et al. (1991), with some modification. Cerebella were dissected from 14 - to 15-day-old Wistar rats and placed on agar immersed in icecooled basal salt solution (BSS) containing 124 $\mathrm{mm} \mathrm{NaCl}, 3.5 \mathrm{~mm} \mathrm{KCl}, 1.25 \mathrm{~mm} \mathrm{NaH}_{2} \mathrm{PO}_{4}, 2.0 \mathrm{~mm}$ $\mathrm{MgSO}_{4}, 2.5 \mathrm{~mm} \mathrm{CaCl}, 10 \mathrm{~mm}$ glucose, and 22.0 $\mathrm{mm} \mathrm{NaHCO}_{3}$ equilibrated with 95\% $\mathrm{O}_{2}+5 \%$ $\mathrm{CO}_{2}$ gas. The vermis was cut sagitally at $400 \mu \mathrm{m}$ thickness with a rotating blade (Rotorslicer, Dosaka-EM, Kyoto, Japan). The slices were then transferred to porous transparent membranes (Cell culture insert, pore size $0.45 \mu \mathrm{m}$, Becton Dickinson, Bedford, MA), placed in six-well chambers with $1.5 \mathrm{ml}$ of culture medium, and maintained in a humidified atmosphere of $5 \% \mathrm{CO}_{2}$ in air at $37^{\circ} \mathrm{C}$. The culture medium was a mixture of $50 \%$ of Dulbecco's modified Eagle medium, 25\% of Hanks' balanced salt solution, and $25 \%$ of horse serum, supplemented with HEPES (final concentration $16.7 \mathrm{~mm}$, buffered to $\mathrm{pH} 7.3$ with $\mathrm{NaOH}$ ), glucose $(4.5 \mathrm{~g} / 1)$, L-glutamine $(0.39 \mathrm{~g} /$ liter $)$, $\mathrm{NaHCO}_{3}(18.9 \mathrm{~mm})$, streptomycin $(0.1 \mathrm{~g} /$ liter $)$, and penicillin $(100 \mathrm{U} / \mathrm{ml}$ ) (all from GIBCO BRL, New York).

\section{ELECTROPHYSIOLOGY}

After cultivation for 2-3 days in vitro, a slice was trimmed to a wedge shape containing a few cortical folia of lobule VI with connected white matter and transferred to a recording chamber (Fig. 1A, below). The population responses of Purkinje cells in a slice to various agonists were recorded by a wedge recording technique (Garthwaite et al. 1986; Ito and Karachot 1989). Briefly, a wedge-like slice was placed in a two-compartment bath and sealed with grease in such a way that its white matter traversed a narrow slit in the septum. The direct current (d.c.) potential between the two compartments was monitored continuously with $\mathrm{Ag} / \mathrm{AgCl}$ electrodes embedded in $4 \%$ agar in saline and a high-input impedance am-

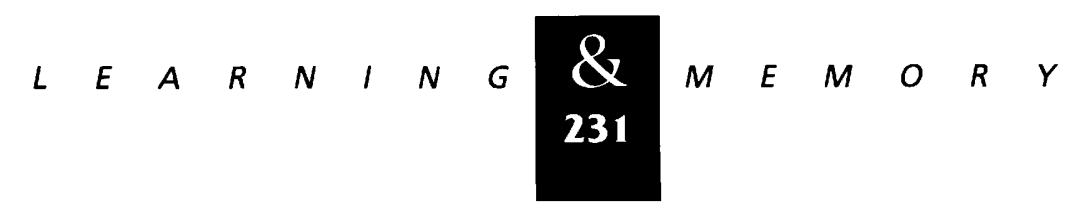


plifier (AN-601G, Nihon-koden, Tokyo, Japan), and displayed on a chart recorder. The d.c. potential reflects the depolarization of the population of the Purkinje cells, because the only axons passing through the grease gap that give rise to the potential difference between the chambers are those of Purkinje cells. The sealing resistance was $50-120$ $\mathrm{k} \Omega$. The chamber was perfused with BSS containing $0.5 \mu \mathrm{M}$ tetrodotoxin (TTX) (Sankyo, Tokyo, Japan) equilibrated with $95 \% \mathrm{O}_{2}+5 \% \mathrm{CO}_{2}$ at a rate of $1.5 \mathrm{ml} / \mathrm{min}$ at $35-36^{\circ} \mathrm{C}$. Test drugs were added to the perfusate.

\section{RNA ISOLATION AND QUANTITATIVE RT PCR}

For RNA analysis of many slices, from which accompanying electrophysiological recordings were not made, whole slices were stimulated as a batch in the same condition, as in wedge recording. Slices on culture membranes were transferred to the chambers ("resting chamber") containing $0.5 \mu \mathrm{M}$ TTX in culture medium and stabilized for 2 $\mathrm{hr}$. They were then rapidly transferred to chambers containing test drugs and TTX in medium, stimulated for a defined period, rinsed in another chamber, and returned to the resting chamber. Total cellular RNA was extracted from slices as described by Chomczynski and Sacchi (1987). In some experiments total RNA was recovered from a wedge-like slice after electrophysiological study. The yields of total RNA from whole slices and wedge-like slices were $\sim 10 \mu \mathrm{g}$ and $1 \mu \mathrm{g}$, respectively. Reverse transcription was performed to synthesize cDNA from $0.5-\mu \mathrm{g}$ samples of total RNA using $5 \mathrm{U} / \mu \mathrm{l}$ of Moloney murine leukemia virus (MMLV)-reverse transcriptase (RT) (Superscript II, GIBCO-BRL, NY) at $42^{\circ} \mathrm{C}$ for $1 \mathrm{hr}$ in $20 \mu \mathrm{l}$ of reaction buffer containing $50 \mathrm{~mm}$ Tris- $\mathrm{HCl}(\mathrm{pH}$ 8.3), 75 mм KCl, 3 mм $\mathrm{MgCl}_{2}, 10 \mathrm{~mm}$ DTT, $0.5 \mathrm{~mm}$ dNTP, and $25 \mu \mathrm{g} / \mathrm{ml}$ of oligo(dT) $)_{16}$.

A volume of $1 \mu \mathrm{l}$ of the cDNA solution (corresponding to $25 \mathrm{ng}$ of total RNA) was amplified by polymerase chain reaction (PCR) with 0.02 $\mathrm{U} / \mu \mathrm{l}$ of Taq polymerase (AmpliTaq, Perkin-Elmer Cetus, Norwalk, CT) in $50 \mu \mathrm{l}$ of reaction buffer containing $10 \mathrm{~mm}$ Tris- $\mathrm{HCl}(\mathrm{pH} \mathrm{8.3)}, 50 \mathrm{~mm} \mathrm{KCl}$, $1.5 \mathrm{mM} \mathrm{MgCl}_{2}, 0.001 \%$ gelatin, $0.2 \mathrm{mM} \mathrm{dNTP}, 0.21$ $\mu \mathrm{M}$ of each primer, and $1.11 \mathrm{kBq} / \mu \mathrm{l}(\sim 0.01 \mu \mathrm{M})$ $\left[\alpha-{ }^{32} \mathrm{P}\right] \mathrm{dCTP}$. The amplified cDNA was resolved by 4\% polyacrylamide gel electrophoresis (PAGE), and the dried gel was exposed to an imaging plate and analyzed with a laser-scanning imaging system (BAS2000, Fuji film, Tokyo, Japan). The imaging plate has a very wide and linear dynamic range of about four digits (i.e., $10^{4}$ ), in addition to its high sensitivity to radioactivity, and is thus best suited for quantitative measurement of the mRNA level.

To correct for variation in recovery of RNA, in efficiency of reverse transcription, and in efficiency of amplification, we adopted the method of coamplification of endogenous mRNA (Chelly et al. 1988; Noonan et al. 1990). Glyceraldehyde phosphate dehydrogenase (GAPDH) cDNA, which is expressed ubiquitously and constitutively, was thus amplified with a second set of primers in the same PCR tube and used as an internal control. The radioactivity of the cDNA of interest was normalized to that of GAPDH CDNA in each sample. To assure the linearity of our RT-PCR assay, we performed preliminary experiments for each cDNA to be analyzed, by sampling $5-\mu l$ aliquots at every third cycle of the reaction. We found, for example, that the linear range for GAPDH was between 21 and 30 cycles, and for BDNF, between 31 and 40 cycles. Thus PCR was usually carried out first with a set of primers for BDNF for seven cycles, and then a set of primers for GAPDH was added to the PCR tube for a further 27 cycles. One normalized value means that the level of BDNF mRNA is about $2^{-7}$ of that of GAPDH mRNA in this case.

One cycle of PCR consisted of denaturation at $94^{\circ} \mathrm{C}$ for $30 \mathrm{sec}$, primer annealing at $60^{\circ} \mathrm{C}$ for 45 sec, and primer extension at $72^{\circ} \mathrm{C}$ for $45 \mathrm{sec}$. The sequences of primer sets were as follows (from $5^{\prime}$ to $3^{\prime}$ ): (NGF) sense TCTCCTTCAACAGGACTCACAG, antisense ACACACGCAGGCTGTATCTATC; (CNTF) sense GAGAACCTCCAGGCTTACCGT, antisense TGGCTCTCAAGTGCTGAGATTC; (FGF) sense ATCCCAAGCGGCTCTACTGCA, antisense AACAGTATGGCCTTCTGTCCAG; (GAPDH) sense CTGGAGAAACCTGCCAAGTATG, antisense CACCCTGTTGCTGTAGCCATAT; [BDNF, exon 5 (common)] sense GCACGTGATCGAAGAGCTGCT, antisense GTCTATCCTTATGAACCGCCAG; (BDNF, exon 1) sense TAAGACACTGAGTCTCCAGGAC; (BDNF, exon 2) sense AGTGTTTATCTCCAGGATCTAGC; (BDNF, exon 3) sense GAGCAGCTGCCTTGATGTTTAC; (BDNF, exon 4) sense AGCGTGACAACAATGTGACTCC; (BDNF, exon 1-4) antisense GCCTTCATGCAACCGAAGTATG.

\section{VIABILITY ASSAY}

Lactate dehydrogenase (LDH) released from damaged cells was determined from aliquots of

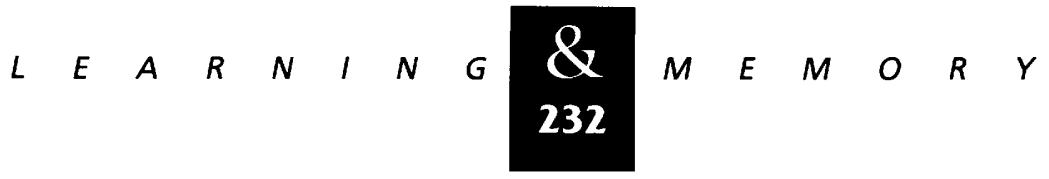


culture medium. The remaining cellular LDH was determined by lysing cells with a $0.2 \%$ Triton X-100 in PBS for $10 \mathrm{~min}$. LDH activity in 50- $\mu 1$ samples of medium or cell lysates was measured using an LDH assay kit (Sigma, St. Louis, MO) and procedures specified by the supplier. The amount of $\mathrm{LDH}$ activity in the medium was normalized to total activity.

\section{ISOLATION OF PURKINJE CELLS AND GRANULE CELLS}

Purkinje and granule cells were purified by reported methods (Sellinger et al. 1974; Mikoshiba et al. 1979), with minor modifications for smallscale samples. Briefly, 45 cultured slices, which were either stimulated or unstimulated (control), were cut into $\sim 0.5-\mathrm{mm}$ squares on ice and suspended in $7.5 \%$ polyvinyl pyrrolidone containing $1 \%$ bovine serum albumin (BSA) and $3.77 \mathrm{~mm}$ $\mathrm{CaCl}_{2}$. The suspension was pushed gently through a series of nylon meshes with pore sizes of 750 , 300,108 , and $70 \mu \mathrm{m}$. The sieved suspension was layered over a three-step gradient of 2.3, 1.75, and $1.0 \mathrm{~m}$ sucrose containing $1 \% \mathrm{BSA}$ and centrifuged at $41,000 \mathrm{~g}$ for $30 \mathrm{~min}$ at $4^{\circ} \mathrm{C}$ in a Beckman SW55Ti rotor. The fine band at the $2.30-1.75 \mathrm{~m}$ interface, which corresponds to cerebellar neurons, was collected, filtered through a nylon mesh of $59 \mu \mathrm{m}$ pore size, layered on a three-step gradient of 2.3, 1.9 , and $1.75 \mathrm{M}$ sucrose containing $1 \% \mathrm{BSA}$, and centrifuged at $110,000 \mathrm{~g}$ for $2 \mathrm{hr}$ at $4^{\circ} \mathrm{C}$ in an SW55Ti rotor. Purkinje cells were recovered from the 1.9-1.75 $\mathrm{m}$ interface and granule cells from the 2.3-1.9 M interface.

The purity of preparations was determined by immunocytochemical examination of inositol trisphosphate receptor $\left(\operatorname{IP}_{3} R\right)$ protein, a specific marker of Purkinje cells. Isolated cells were plated on coverslips coated with poly-L-lysine (Sigma, St. Louis, $M O)$, treated with anti-IP ${ }_{3} R$ monoclonal antibody (18A10), and stained by the avidin-biotin complex method with diaminobenzidine as a chromogen, as described previously (Yuzaki and Mikoshiba 1992).

\section{DRUGS}

AMPA, quisqualate, trans-ACPD, and L-aspartate (all from Tocris Neuramin, Bristol, UK) were dissolved in water as $1000 \times$ stock solutions (the $\mathrm{pH}$ was adjusted when necessary) and frozen at $-40^{\circ} \mathrm{C}$ until use.

\section{STATISTICAL ANALYSIS}

Data are expressed as means \pm standard error of the mean (s.E.M.). Statistical significance was analyzed by Student's $t$-test.

\section{Results}

STIMULUS CONDITIONS FOR INDUCTION OF LTDA IN CULTURED SLICES

Our initial experiments showed that the procedures for preparing acute slices sometimes significantly increased the expressions of immediate early genes (IEGs) such as c-fos, c-jun, and zif/ 268 , which could conceivably interfere with the expression of late genes. Therefore, to investigate long-lasting changes in gene expression associated with cerebellar neuronal activity reproducibly, we used short-term cultured cerebellar slices instead of freshly isolated slices. The low levels of expression of IEGs were restored and remained at low levels after 1-2 days in culture. The slices could be maintained for $>2$ weeks.

The responses of Purkinje cells in cultured slices were recorded by a wedge recording technique (Garthwaite et al. 1986; Ito and Karachot 1989) (Fig. 1A). Application of $10 \mu \mathrm{M}$ AMPA for 2 min induced responses of $\sim 0.2-0.6 \mathrm{mV}$, which could be evoked repeatedly with little sign of desensitization (data not shown). Application of 100 $\mu \mathrm{M}$ quisqualate for $5 \mathrm{~min}$ as a conditioning stimulus caused the desensitization of succeeding AMPA responses (Fig. 1B, upper trace) for at least $4 \mathrm{hr}$, whereas application of $10 \mu \mathrm{M}$ AMPA for $5 \mathrm{~min}$ did not (Fig. 1B lower trace). The desensitization of AMPA responses was not caused by deterioration of neurons in the slices because the responses to 3 mM L-aspartate before and after the conditioning stimuli were similar (Fig. 1B). These data are summarized in Figure $1 \mathrm{C}$. In addition, lactate dehydrogenase (LDH) leakage in the medium $2 \mathrm{hr}$ after stimulation, expressed as a percentage of that before stimulation, was $108 \pm 8 \%(n=3), 102 \pm 7 \%$ $(n=3)$, and $111 \pm 6 \%(n=3)$ after a 5-min application of $10 \mu \mathrm{M}$ AMPA, $100 \mu \mathrm{M}$ quisqualate, and medium only, respectively, indicating that the desensitization of AMPA response induced by quisqualate was not attributable to damaged neurons. Thus, LTDA of Purkinje cells could be induced in cultured slices.

Next, we investigated the stimulation conditions for induction of LTDA in cultured slices in detail. As shown in Figure 3A (below), application

$$
\text { n....... 圈"no. }
$$


$\mathbf{A}$

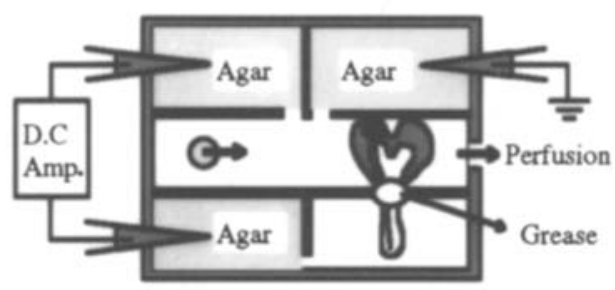

B
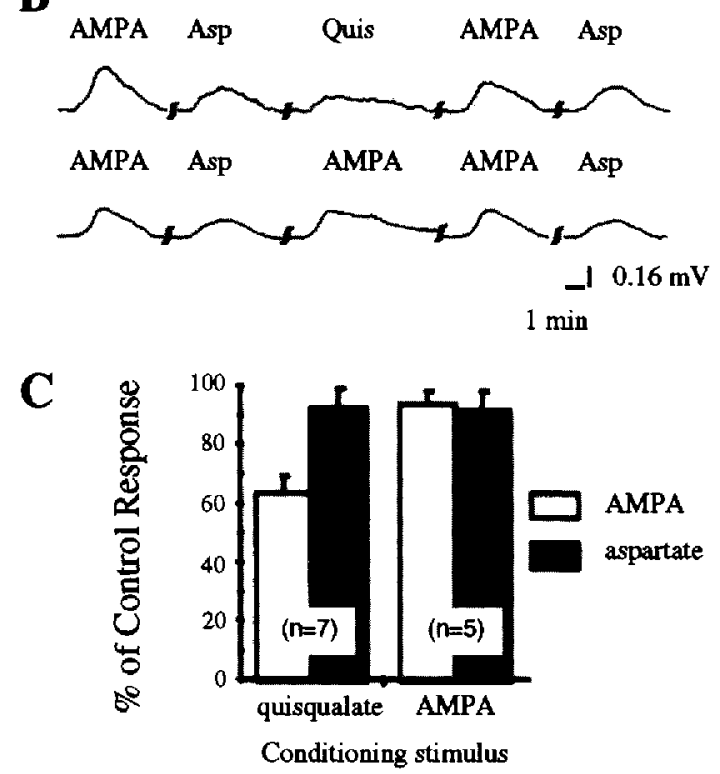

Figure 1: Wedge recording and induction of long-term desensitization of AMPA responses in cultured cerebellar slices. (A) Diagram of the perfusion chamber. A cultured slice cut into a wedge shape was placed in a two-compartment bath. Gray matter containing Purkinje cell somata was perfused with test solution and separated from white matter in the adjacent compartment by grease. The potential difference between the two compartments was monitored with $\mathrm{Ag} / \mathrm{AgCl}$ electrodes embedded in $4 \%$ agar in saline. (B) Representative wedge recordings. One hour after conditioning with $100 \mu \mathrm{M}$ quisqualate (Quis) for $5 \mathrm{~min}$, the response to $10 \mu \mathrm{M}$ AMPA remained desensitized to $-35 \%$ of the response $10 \mathrm{~min}$ before conditioning, whereas the response to $3 \mathrm{~mm}$ L-aspartate (Asp) was not changed significantly (upper trace). The AMPA and Asp responses were not changed by conditioning with $10 \mu \mathrm{M}$ AMPA for $5 \mathrm{~min}$ (lower trace). (C) Summary of results on conditioning stimulus. The degrees of desensitization at $1 \mathrm{hr}$ after conditioning are expressed as percentages of the control response before conditioning stimulus. Conditioning with quisqualate $(100 \mu \mathrm{M})$, but not AMPA $(10 \mu \mathrm{M})$, for 5 min significantly desensitized subsequent AMPA responses (open columns). Responses to aspartate $(3 \mathrm{~mm})$ remained unchanged (shaded columns) with both conditioning stimuli. The numbers in parentheses show the number of slices. Bars with asterisks indicate significant change: $\left(^{*}\right)$ $P<0.05$; and $\left(^{* *}\right) P<0.01$, compared with the AMPA response after conditioning with AMPA $(10 \mu \mathrm{M})$ for $5 \mathrm{~min}$. of $100 \mu \mathrm{M}$ quisqualate for 3 or $4 \mathrm{~min}$ did not induce LTDA, whereas conditioning with quisqualate for $5 \mathrm{~min}$ induced LTDA consistently. Conditioning with quisqualate for $6 \mathrm{~min}$ also induced LTDA consistently, but application of $10 \mu \mathrm{M}$ AMPA for $6 \mathrm{~min}$ as a conditioning stimulus also caused sizable ITDA. This suggests that prolonged application of AMPA can substitute for quisqualate, possibly because a large influx of $\mathrm{Ca}^{2+}$ can activate phospholipase $C$ without activation of mGluR (Eberhard and Holz 1988). As shown in Figure 3B, quisqualate at 10 and at $30 \mu \mathrm{M}$ did not induce LTDA reliably, whereas at $100 \mu \mathrm{M}$ it consistently induced LTDA. Thus, the application duration and the dose of quisqualate for the induction of LTDA were in good agreement with those on freshly isolated cerebellar slices (Ito and Karachot 1989).

In the following study where electrophysiological recording was not routinely conducted, we thus applied $100 \mu \mathrm{M}$ quisqualate for $5 \mathrm{~min}$ as a specific stimulus for induction of LTDA, and $10 \mu \mathrm{M}$ AMPA or medium alone for $5 \mathrm{~min}$ as controls. This condition reliably induced LTDA that could be followed at least up to $4 \mathrm{hr}$ without signs of recovery.

\section{QUISQUALATE SPECIFICALLY INCREASED BDNF MRNA}

As shown in Figure 2A, quisqualate, applied at $100 \mu \mathrm{M}$ for $5 \mathrm{~min}$ increased the expression of BDNF significantly. Stimulation with $10 \mu \mathrm{M}$ AMPA did not increase the BDNF mRNA but it caused a significant and larger increase in nerve growth factor (NGF) mRNA than quisqualate did. This suggests that quisqualate-induced NGF expression is mediated by AMPA receptor activation by quisqualate. The other neurotrophic factors studied, ciliary neurotrophic factor (CNTF) and basic fibroblast growth factor (FGF), did not show any increase on AMPA or quisqualate treatment. Thus the BDNF mRNA was increased specifically by the quisqualate stimulus.

Next, we analyzed the time course of expression of BDNF mRNA. As shown in Figure 2, B and C, BDNF mRNA increased significantly $4 \mathrm{hr}$ after application of quisqualate and remained at a high level even $16 \mathrm{hr}$ after the stimulus. NGF mRNA also followed a similar time course of expression with a peak at $4 \mathrm{hr}$ after stimulation (Fig. 2C, right), but the other neurotrophic factors tested remained relatively constant during the observed period (data not shown). The level of GAPDH mRNA expression, the internal control of mRNA quantification, remained almost constant (Fig. 2B).

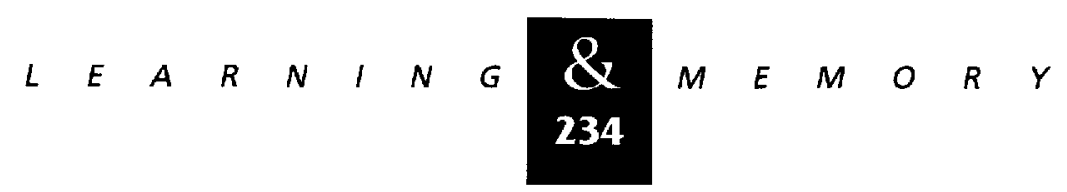



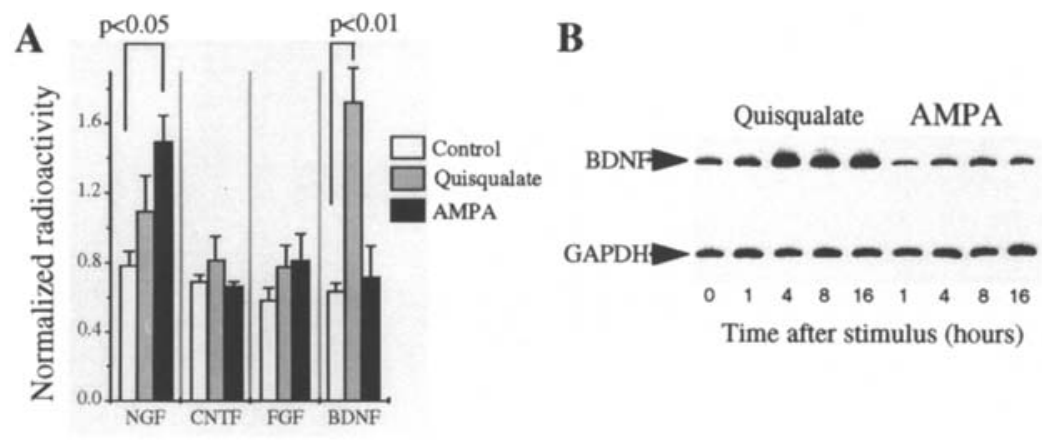

Figure 2: Specific increase in BDNF $m R N A$ by quisqualate and its time course. (A) Cerebellar slices were stimulated by $100 \mu \mathrm{M}$ quisqualate or by $10 \mu \mathrm{M}$ AMPA or medium alone as controls, each for 5 min. mRNAs for NCF, CNTF, FGF, and BDNF were analyzed as described in Materials and Methods. NGF mRNA was significantly elevated by AMPA stimulation $(P<0.05)$, and BDNF mRNA specifically by quisqualate $(P<0.01)(n=3)$. (B) Slices were stimulated in the same way as $A$. Total RNA was extracted $1,4,8$, and $16 \mathrm{hr}$ after conditioning, and RT-PCR was performed as described in Materials and Methods. Bands with arrows correspond to amplified cDNAs for BDNF (511 bp) and for GAPDH (228 bp). (C) Time course of increase in BDNF (left) and NGF (right) mRNA. Radioactivity of amplified CDNA was normalized to that of GAPDH CDNA and plotted against time.

STIMULUS CONDITIONS FOR INCREASES OF BDNF MRNA AND COMPARISON WITH THAT FOR LTDA

The BDNF mRNA level was increased by application of $100 \mu \mathrm{M}$ quisqualate for 5 min or more, but not for $4 \mathrm{~min}$ or less (Fig. 3A, left). It was also increased by application of AMPA for $6 \mathrm{~min}$. The expression of BDNF mRNA was thus dependent on the duration of stimulation in the same way as was the induction of LTDA (Fig. 3A, right).

The dose response of BDNF mRNA expression indicated that an increase was not observed on application of $10 \mu \mathrm{M}$ quisqualate, but at higher concentrations of quisqualate up to $100 \mu \mathrm{M}$, it increased in a dose-dependent manner (Fig. 3B, left). This finding was also consistent with results on induction of LTDA (Fig. 3B, right).

Application of AMPA (10 $\mu \mathrm{M})$ or mGluR agonist trans-ACPD $(300 \mu \mathrm{M})$ alone failed to increase the BDNF mRNA level (Fig. 3C, left) or to induce LTDA (Fig. 3C, right). Coactivation of AMPA and mGlu receptors induced significant LTDA and increased BDNF mRNA to some extent. This suggests that both LTDA induction and BDNF mRNA expression involves the coactivation of AMPA and $m$ Glu receptors. The difference in the ability of combined AMPA and trans-ACPD application to induce LTDA and BDNF mRNA expression may suggest that there is some mechanistic dissociation between the two phenomena, that needs further study.
It should also be noted that the BDNF mRNA expression and the LTDA induced by coapplication of AMPA and trans-ACPD $(300 \mu \mathrm{M})$ were less than those induced by quisqualate (Fig. 3C). This was also the case when a higher concentration of trans-ACPD (1 mM) was used (data not shown). This may be because trans-ACPD is a weak and partial agonist in activating the mGluR 1 subtype of metabotropic glutamate receptors, which is expressed in both granule and Purkinje cells (Aramori and Nakanishi 1992; Yuzaki and Mikoshiba 1992). In addition, trans-ACPD is a very potent agonist of mGluR2 in Golgi and granule cells in the cerebellum, and it also effectively activates mGluR3 in glial cells (Tanabe et al. 1992). Thus, the activation of mGluR 1 by the more potent agonist quisqualate may be more effective for the induction of BDNF mRNA and LTDA.

In summary, quisqualate induced both LTDA and BDNF mRNA expression with a very similar dose and duration of application. Their induction involves activation of both AMPA receptor and $\mathrm{mGluR}$ (probably mGluR1). These results suggest that BDNF mRNA may be coinduced by L'TDA-cvoking stimulation and shares some common pathways of induction.

\section{INCREASE IN BDNF MRNA IN GRANULE AND PURKINJE CELLS}

We analyzed the cells responsible for the increase in BDNF mRNA. We used a cell fraction-

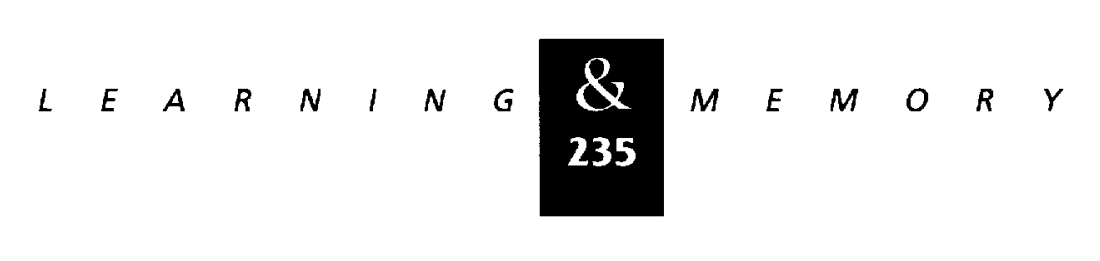


Figure 3: Stimulus conditions for increasing BDNF mRNA and comparison with that for LTDA. (A) Effect of duration of drug application. Cultured cerebellar slices were conditioned with $100 \mu \mathrm{M}$ quisqualate (shaded columns), or with $10 \mu \mathrm{M}$ AMPA (solid columns) for indicated durations. Radioactivity of BDNF mRNA at $4 \mathrm{hr}$ after stimulation was analyzed and normalized to GAPDH mRNA (left). The degree of LTDA at $1 \mathrm{hr}$ was expressed as percentage of the control AMPA response (right). Most of the LTDA results were obtained from separate experiments using wedge recording to monitor LTDA for typically $1 \mathrm{hr}$. From at least one wedge in each treatment, we recovered RNA after electrophysiological recordings. The desensitization values at $1 \mathrm{hr}$ were quite similar to those at $4 \mathrm{hr}$ after induction of LTDA, and increases in BDNF mRNA were also similar to the increases observed without electrophysiological recordings, giving the rationale for comparison. (B) Effect of quisqualate concentration. Slices were stimulated by indicated concentrations of quisqualate for $5 \mathrm{~min}$. Expression of BDNF mRNA (left) and degree of desensitization (right) are shown as described in A. (C) Effect of AMPA and trans-ACPD. Slices were conditioned with $10 \mu \mathrm{M}$ AMPA, $300 \mu \mathrm{M}$ transACPD, $10 \mu \mathrm{M}$ AMPA $+300 \mu \mathrm{m}$ trans-ACPD, or $100 \mu \mathrm{m}$ quisqualate for $5 \mathrm{~min}$. Expression of BDNF mRNA (left) and degree of desensitization (right) are shown as described in $A$. Numbers in parentheses indicate numbers of samples studied. Bars with asterisks indicate significant change: $\left(^{*}\right) P<0.05 ;\left({ }^{* *}\right)$ $P<0.01$, compared with the value for $5-\mathrm{min}$ application of AMPA $(A, C)$ or no drug (concentration 0$)(B)$.

ation technique (Fig. 4A) (Sellinger et al. 1974; Mikoshiba et al. 1979), and not an in situ hybridization (ISH) technique, because (1) the sensitivity of ISH was not comparable to that of RT-PCR used in other parts of this study, (2) relatively high resting levels of BDNF mRNA expression in the granule cell layer of cerebellum of 14- to 15-dayold rats made it difficult to quantify the changes in Purkinje cells by ISH, (3) in general, quantification of two- to threefold changes in mRNA by ISH is difficult.

Fractionation of cerebellar neurons has the advantage that Purkinje cells and granule cells, major constituents of cerebellar neurons, differ greatly in size, and so can be separated easily by density gradient centrifugation. Contamination of the granule cell fraction with Purkinje cells was $<1 \%$, as judged by immunocytochemical staining of $\mathrm{IP}_{3} \mathrm{R}, \mathrm{a}$ specific marker of Purkinje cells (Fig. 4A, right). Contamination of the Purkinje cell fraction with granule cells was difficult to assess because of lack of a good marker of granule cells, but estimated to be $\sim 2 \%$ by morphological examination (Fig. $4 \mathrm{~A}$,

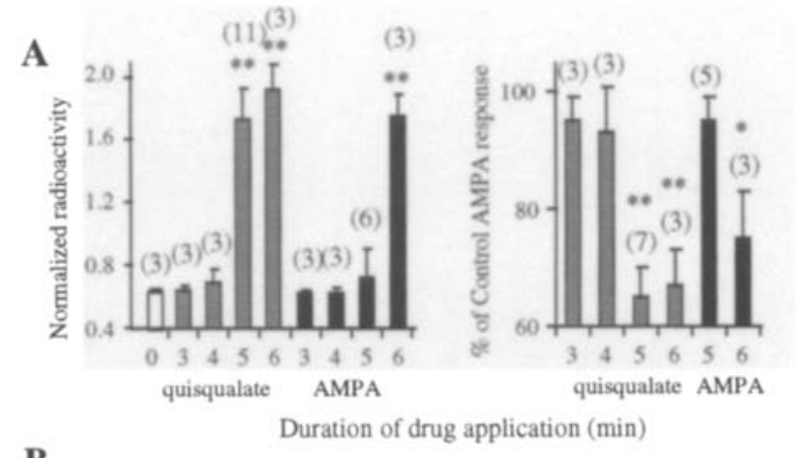

B
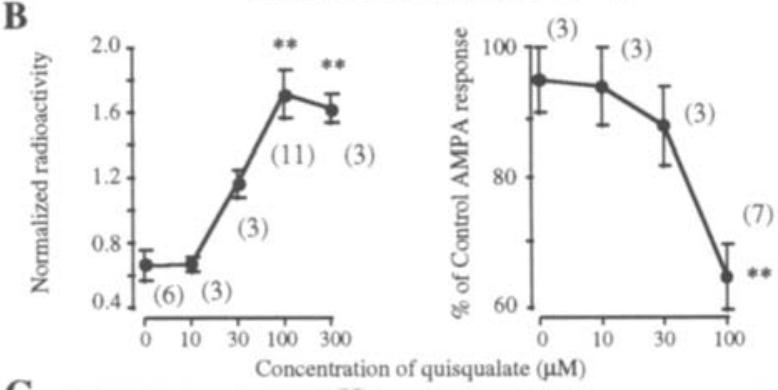

C

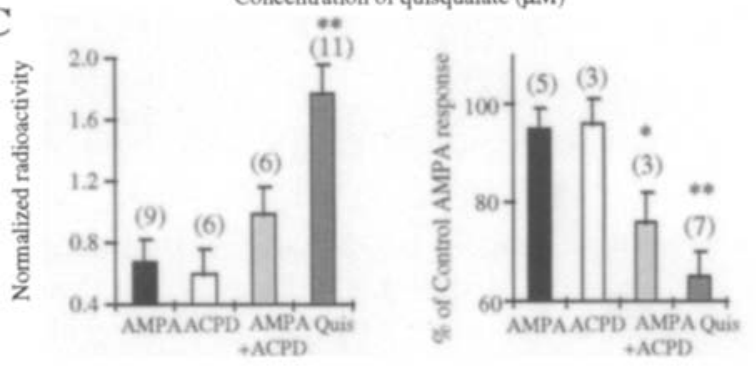

left). These estimations are generally in good agreement with results of an earlier study (Sellinger et al. 1974).

In unstimulated slices, BDNF mRNA was expressed in granule cells at a level $\sim 24$ times higher than in Purkinje cells (Fig. 4B). Stimulation by quisqualate increased the expression in granule and Purkinje cells to $\sim 2.5$ and 2.8 times higher levels, respectively, than those in unstimulated slices (Fig. 4B). These values are similar to those obtained in unseparated cells (Figs. 2 and 3), indicating that the fractionation procedure did not affect the succeeding mRNA analyses. As there are - 250-900 times more granule cells than Purkinje cells (Ito 1984), the levels of BDNF mRNA observed in cerebellar slices at rest and after stimulation by quisqualate are mainly attributable to those in granule cells. It should be noted that BDNF mRNA was also expressed in the Purkinje cell fraction and was increased by stimulation.

Whereas we cannot fully rule out the possibility that some of the BDNF mRNA observed in the Purkinje cell fraction was caused by contamina- 
$\mathbf{A}$
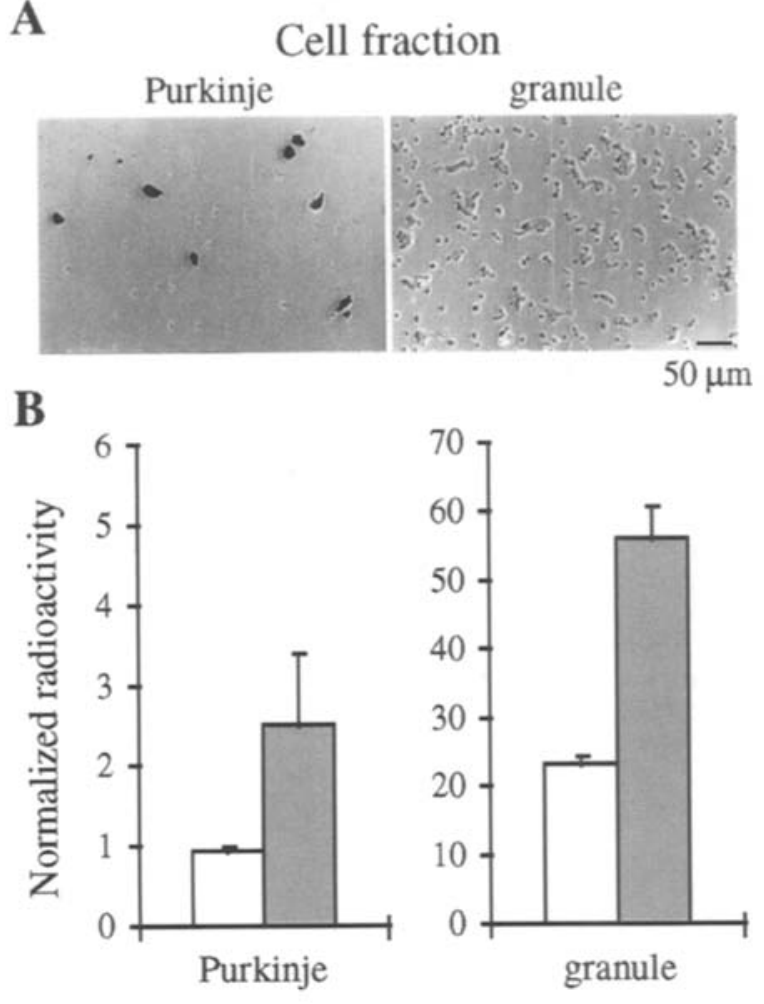

Figure 4: Appearance of Purkinje and granule cells and BDNF mRNA after fractionation. (A) Appearances of the Purkinje cell fraction (left) and granule cell fraction (right) by phase-contrast microscopy. Cells were treated with monoclonal antibody against $I P_{3} R$, a specific marker of Purkinje cells, and stained by the avidin/biotin/peroxidase method using diaminobenzidine as a chromogen. Scale bar, $50 \mu \mathrm{m}$. (B) Cerebellar slices were treated with $100 \mu \mathrm{M}$ quisqualate (shaded column) for 5 min as an LTDA-evoking stimulus or medium alone as a control (open column). After $4 \mathrm{hr}$, the Purkinje cell and granule cell fractions were purified as described in Materials and Methods. BDNF mRNA normalized by GAPDH mRNA was assayed in the Purkinje cell (left) and granule cell (right) fraction as described in Materials and Methods. Data in $B$ were obtained from two independent experiments.

tion with granule cells, we consider it unlikely because promoter usage in generation of elevated levels of variant BDNF mRNAs in the Purkinje cell differed from that in the granule cell fraction (see below).

THE PROMOTER USED IN QUISQUALATE-INDUCED ELEVATION OF BDNF MRNA

Recently, it has been reported that the rat BDNF gene consists of four short $5^{\prime}$ exons with different promoter regions and one 3 ' exon en- coding the mature BDNF protein and that alternative usage of four promoters and differential splicing control tissue-specific and seizure-induced expression of BDNF mRNA (Timmusk et al. 1993; Kokaia et al. 1994). To determine which promoters are used for the increased BDNF mRNA on quisqualate stimulation, we next used exon-specific primers for RT-PCR.

We first applied RT-PCR with these primers in a kainate-induced seizure model (Timmusk et al. 1993) to evaluate the specificity of our method. As shown in Figure 5A, marked increases in BDNF mRNA containing exons 1 and 3 were found in the hippocampus $4 \mathrm{hr}$ after injection of kainate, compared with the level in saline-injected control animals. Transcripts with exon 1 and exon 3 increased 18.3- and 12.1-fold, respectively, over the control levels, whereas transcripts with exons 2 and 4 increased 3.4 - and 2.5 -fold, respectively. These results are very similar to those obtained by Northern hybridization (Timmusk et al. 1993), confirming the specificity of our method. We found that transcripts with exons 1 and 3 also increased specifically in the cerebellum, although their total increase was less than in the hippocam. pus (Fig. 5A, right).

To determine whether Purkinje and granule cells use different promoters, we studied exon usage in isolated cells (Fig. 5B, right). Exon 1 was mainly used in both cell types after stimulation with quisqualate, its usage increasing about 2.6- to 2.7-fold. In granule cells, transcripts with exons 3 and 4 increased 1.9. and 2.1-fold, respectively. These increases were similar to those in unfractionated slices (Fig. 5B, left), indicating again that the increase in BDNF mRNA in unfractionated slices mainly reflected the change in granule cells. In the Purkinje cell fraction, however, levels of BDNF mRNA transcripts with exon 2 were relatively higher, and those with exon 3 , lower, than in the granule cell fraction and total slices. In contrast, in unstimulated slices, there was no difference in exon usage of BDNF mRNA transcripts between granule and Purkinje cells. They consisted of exon $3>$ exon 2 and exon 4 (data not shown). These results suggest that Purkinje cells specifically use exon 2 instead of exon 3 in response to stimulation by quisqualate.

\section{Discussion}

In this study we have shown delayed changes of gene expression after induction of LTDA in cer-

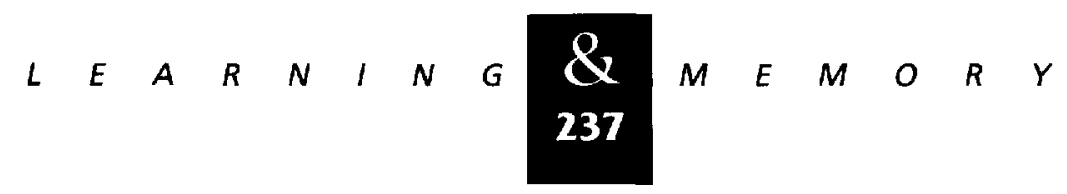


A Kainate-induced seizure in vivo
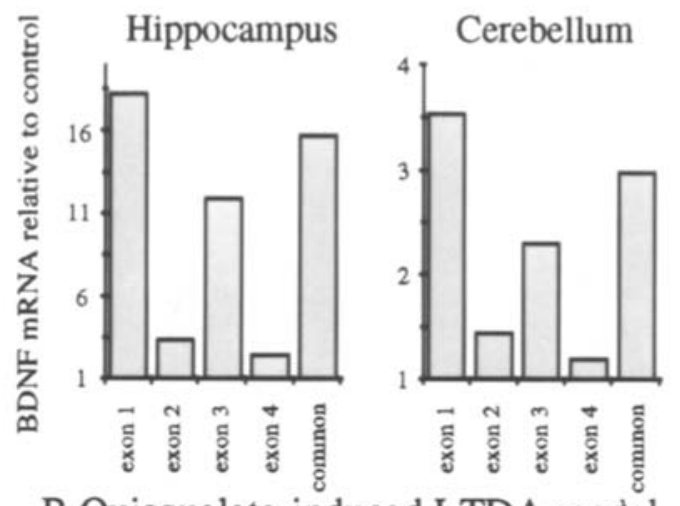

B Quisqualate-induced LTDA model

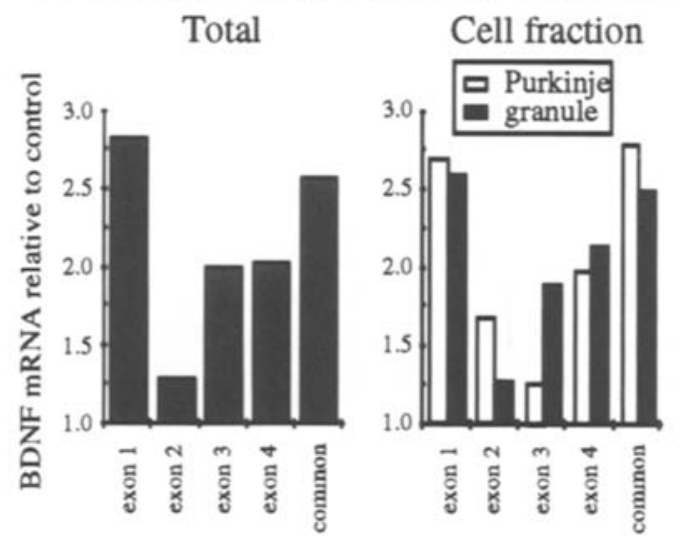

Figure 5: Expression of BDNF mRNA containing different 5 ' exons after seizure induced by kainate and after stimulation by quisqualate. (A) Adult rats (weight 210 220 grams) were injected intraperitoneally with kainate $(12 \mathrm{mg} / \mathrm{kg}$ body weight) or saline as a control. Total RNA was prepared from the hippocampus (left) and cerebellum (right) $4 \mathrm{hr}$ later, and BDNF transcripts were analyzed with different exon-specific primers as described in Materials and Methods. Data are expressed relative to control levels. (B) Cultured cerebellar slices were treated with $100 \mu$ mquisqualate for $5 \mathrm{~min}$ as an LTDA-evoking stimulus or medium alone as a control ( 45 slices for each treatment). After $4 \mathrm{hr}$, slices were cut into pieces as described in Materials and Methods, and $\sim 1$ out of 45 chopped slices were reserved for the analysis of unfractionated slices, and the remainder were fractionated. BDNF transcripts with different 5 ' exons were analyzed in unfractionated slices (left) or in fractionated granule and Purkinje cells (right). Data were obtained from one experiment and expressed relative to control levels. Similar results were obtained in another set of experiments.

ebellar slices. Of the neurotrophins studied, BDNF mRNA was specifically increased, and using cell fractionation, the observed changes could be shown to occur in two main types of neurons, Purkinje and granule cells. In addition, quisqualate-induced expression of BDNF mRNA in the cerebellum and in fractionated cells was found to involve a unique pattern of exon usage.

\section{SPECIFIC INDUCTION OF BDNF MRNA BY QUISQUALATE IN THE CEREBELLUM}

Quisqualate, applied under conditions similar to those for inducing LTDA, increased BDNF mRNA after $4 \mathrm{hr}$. Neurotrophin expression in neurons has been shown to be increased by neuronal activity in the forebrain, especially in the hippocampus (Gall and Isackson 1989; Zafra et al. 1990; Ernfors et al. 1991; Isackson et al. 1991; Lu et al. 1991; Lindvall et al. 1992). The stimulation used in most studies involved a variety of strong pathological stimuli, such as experimentally induced seizure (Gall and Isackson 1989; Zafra et al. 1990; Ernfors et al. 1991; Isackson et al. 1991), insulininduced hypoglycemic coma and cerebral ischemia (Lindvall et al. 1992), and prolonged exposure to high potassium solution in vitro (Lu et al. 1991 ). Recently, Bessho et al. (1993) showed that BDNF mRNA was increased by quisqualate in cerebellar granule cells, although the condition for stimulation was not physiological, as it involved $0.5-4 \mathrm{hr}$ in dispersed culture. We found that the expression of this neurotrophin is increased in the cerebellar slice by more moderate stimulation, suggesting that BDNF mRNA may be controlled under physiological neuronal activity in the cerebellum.

The level of increase in BDNF mRNA in the cerebellum following mild quisqualate stimulation was about threefold above that of the control value and less than one-fifth of that in the hippocampus after kainate-induced seizure (Fig. 5A), and that of other earlier studies using strong stimuli. The level of increase was, however, comparable to the two- to threefold increase in the hippocampus after LTP-evoking stimulation (Patterson et al. 1992; Castrén et al. 1993), suggesting that the physiological range of increase in BDNF mRNA may be similar in different brain regions.

It is interesting that of the neurotrophins studied, BDNF mRNA was specifically increased by quisqualate (Fig. 3B). In earlier studies, NGF mRNA was usually coinduced by the stimulus that induced BDNF mRNA (Zafra et al. 1990; Isackson

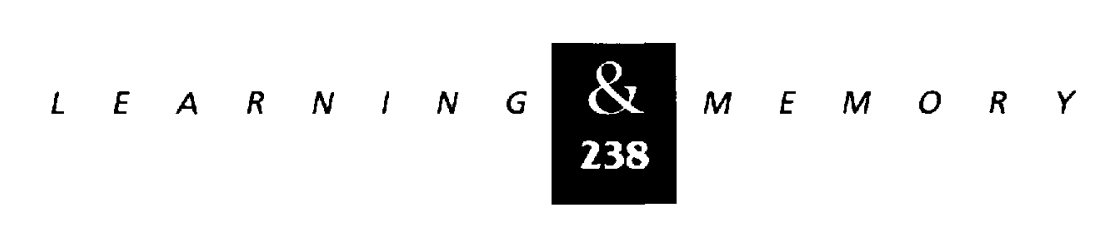


et al. 1991; Lindvall et al. 1992; Zafra et al. 1992). One explanation for the specific induction of BDNF mRNA that was observed in the cerebellum is that it results from the milder stimulus used, consistent with specific increases in BDNF mRNA in the visual cortex following illumination (Castrén et al. 1992) and in the hippocampal CA1 area following LTP (Patterson et al. 1992). If this were the case, then NGF mRNA would be expected to be coinduced with BDNF mRNA by a stimulus of higher intensity. However, AMPA, which caused more depolarization than quisqualate (Fig. 1B) and increased NGF mRNA, failed to increase BDNF mRNA (Fig. 2A). This suggests the alternative explanation that the specific increase of BDNF mRNA may mainly be attributable to the activation of mGluR by quisqualate.

EXON USAGE OF BDNF MRNA IN THE CEREBELLUM AND CELLULAR LOCALIZATION

Recently, alternative usage of four exons of the rat BDNF gene has been reported to control tissue-specific and stimulus-specific regulation of BDNF mRNA expression (Timmusk et al. 1993; Kokaia et al. 1994). However, these reports concern the forebrain, and not the cerebellum. We have showed here that kainate also increases the expression of BDNF mRNA in the cerebellum, with very similar usage of exons as in the hippocampus (Fig. 5A).

Basal and activity-dependent expression of BDNF has been found mainly in granule cells. We consider that at least part of the BDNF mRNA observed in the Purkinje cell fraction reflected the low level of expression of BDNF mRNA in those cells, because the exon usage was different from that in the granule cell fraction. Studies using ISH have shown that BDNF mRNA was not localized to Purkinje cells, but to granule cells in the cerebellum (Hofer et al. 1990; Rocamora et al. 1993). The discrepancy between our results and those of earlier studies can be explained by the higher sensitivity of RT-PCR over ISH. It should also be noted that granule cells are packed more densely than Purkinje cells, as there are $\sim 250-900$ times more granule cells than Purkinje cells (Ito 1984), and thus grain density in granule cell layers is sometimes exaggerated in ISH. Further studies using RT-PCR with single Purkinje cells will be needed to clarify the discrepancy.
FUNCTIONAL SIGNIFICANCE OF INCREASED BDNF MRNA AND RELATIONSHIP WITH LTD

BDNF was initially identified as a trophic factor for peripheral sensory neurons (Barde et al. 1982) and recently has been shown to promote the survival and/or differentiation of mesencephalic dopaminergic neurons and basal forebrain cholinergic neurons (Alderson et al. 1990; Hyman et al. 1991; Knüsel et al. 1991). BDNF has also been shown to regulate the expression of neuropeptides in GABA-ergic neurons (Nawa et al. 1993). During development of the cerebellum, expression of BDNF mRNA is mainly localized in the internal granule cell layer and increases dynamically with a peak around postnatal day 20 (Rocamora et al. 1993), at which time the synapse formation between parallel fibers of granule cells and Purkinje cells is prominent (Altman and Winfree 1977). In contrast, transcripts of the functional BDNF receptor gene, $t r k B$, are expressed predominantly in Purkinje cells (Klein et al. 1990). Although the effect of BDNF on Purkinje cells remains to be determined, these observations suggest that BDNF expressed in granule cells may have a trophic action on Purkinje cells such as maintenance or regulation of synapses between granule cells and Purkinje cells. The BDNF mRNA observed in the Purkinje cell fraction also raises the possibility of autocrine actions of BDNF in these neurons (see also Kokaia et al. 1993; Miranda et al. 1993).

It is not clear whether BDNF mRNA elevation and LTDA are causally related or whether BDNF is involved in the process of LTDA at all. LTD and LTDA are attributable to the reduced AMPA receptor sensitivity in Purkinje cells (Ito and Karachot 1989; Linden et al. 1991). The desensitization of AMPA receptors in Purkinje cells, probably by phosphorylation, is a phenomenon observed within a few minutes of conditioning stimulus that persists for many hours. But information storage, based solely on post-translational modification of proteins such as phosphorylation, is generally considered to deteriorate rapidly (Dudai 1989). Thus, although the time course of BDNF mRNA expression is too slow to account for initial induction, it is possible that BDNF may have some role in later phases of synaptic plasticity, because if LTDA is a basic mechanism of motor learning, it should eventually be transformed into a permanent memory. The efficacy of synaptic transmission can be affected by the morphological changes in the syn-

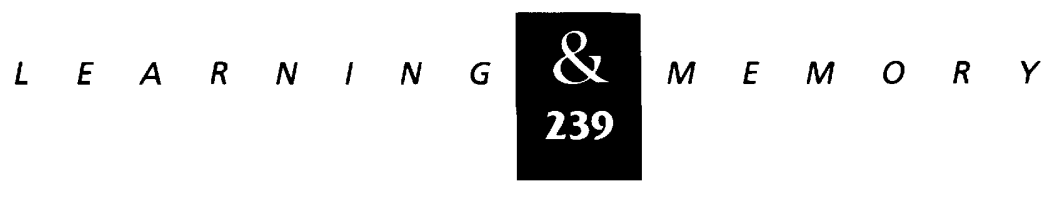


aptic spine or the formation of new synapses, as has been suggested in the hippocampal LTP (Dudai 1989). For example, if the electrical resistance of the synaptic spine neck is decreased or the new synapses are formed on more distal dendrites, the voltage change at the soma induced by the synaptic input may be depressed. The number of synapses per Purkinje cell is reported to increase after motor learning but not after simple exercise (Black et al. 1990; Isaaacs et al. 1992). Consequently, BDNF mRNA expression in granule and Purkinje cells might play a role in such morphological manifestations. Further studies, for example, involving functional ablation of BDNF, will be useful in clarifying the role of this neurotrophin in cerebellar learning.

\section{Acknowledgments}

We thank Dr. H. Miyagawa for technical advice in preparing cerebellar slices, Drs. L. Karachot and M. Ito for generously showing us their experimental setup, and Drs. M. Kano, J.A. Connor, J.J. Petrozzino, B. Lu, and D. Forrest for critical reading of the manuscript. This work was supported by a research grant from the Human Frontier Science Program (to T.F.), a grant from the Brain Science Foundation (to M.Y.), and a grant for the Promotion of Sciences for Japanese Junior Scientists from the Japan Ministry of Education, Science and Culture (to M.Y.)

The publication costs of this article were defrayed in part by payment of page charges. This article must therefore be hereby marked "advertisement" in accordance with 18 USC section 1734 solely to indicate this fact.

\section{References}

Alderson, R.F., A.L. Alterman, Y.A. Barde, and R.M. Lindsay. 1990. Brain-derived neurotrophic factor increases survival and differentiated functions of rat septal cholinergic neurons in culture. Neuron 5: 297-306.

Altman, J. and A.T. Winfree. 1977. Postnatal development of the cerebellar cortex in the rat. V. Spatial organization of Purkinje cell perikarya. J. Comp. Neurol. 171: 1-16.

Aramori, I. and S. Nakanishi. 1992. Signal transduction and pharmacological characteristics of a metabotropic glutamate receptor, mGluR1, in transfected $\mathrm{CHO}$ cells. Neuron 8: 757-765.

Barde, Y.A., D. Edgar, and H. Thoenen. 1982. Purification of a new neurotrophic factor from mammalian brain. EMBO J. 1: 549-553.

Bessho, Y., S. Nakanishi, and H. Nawa. 1993. Glutamate-receptor agonists enhance expression of BDNF mRNA in cultured cerebellar granule cells. Mol. Brain. Res. 18: 201-208.
Black, J.E., K.R. Isaacs, B.J., Anderson, A.A. Alcantara, and W.T. Greenough. 1990. Learning causes synaptogenesis, whereas motor activity causes angiogenesis, in cerebellar cortex of rats. Proc. Natl. Acad. Sci. 87: 5568-5572.

Castrén, E., F. Zafra, H. Thoenen, and D. Lindholm. 1992. Light regulates expression of brain-derived neurotrophic factor mRNA in rat visual cortex. Proc. Natl. Acad. Sci. 89: 9444-9448.

Castrén, E., M. Pitkänen, J. Sirviö, A. Parsadanian, D. Lindholm, H. Thoenen, and P.J. Riekkinen. 1993. The induction of LTP increases BDNF and NGF mRNA but decreases NT-3 mRNA in the dentate gyrus. NeuroReport 4: 895-898.

Chelly, J., J.C. Kaplan, P. Maire, S. Gautron, and A. Kahn. 1988. Transcription of the dystrophin gene in human muscle and non-muscle tissues. Nature 330: 858-860.

Chomczynski, P. and N. Sacchi. 1987. Single-step method of RNA isolation by acid-guanidinium thiocyanate-phenolchloroform extraction. Anal. Biochem. 162: 156-159.

Diamond, J., M. Coughlin, L. Macintyre, M. Holmes, and B. Visheau. 1987. Evidence that endogenous nerve growth factor is responsible for the collateral sprouting, but not the regeneration, of nociceptive axons in adult rats. Proc. Natl. Acad. Sci. 84: 6596-6600.

Dudai, Y. 1989. The neurobiology of memory. Oxford University Press, New York.

Eberhard, D.A. and R.W. Holz. 1988. Intracellular $\mathrm{Ca}^{2+}$ activates phospholipase C. Trends Neurosci. 11: 517-520.

Ernfors, P., J. Bengzon, Z. Kokaia, H. Persson, and O. Lindvall. 1991. Increased levels of messenger RNAs for neurotrophic factors in the brain during kindling epileptogenesis. Neuron 7: 165-176.

Gall, C.M. and P.J. Isackson. 1989. Limbic seizures increase neuronal production of messenger RNA for nerve growth factor. Science 245: 758-761.

Garthwaite, J., G. Garthwaite, and F. Hojos. 1986. Amino acid neurotoxicity: Relationship to neuronal depolarization in rat cerebellar slices. Neuroscience 18: 449-460.

Hémart, N., H. Daniel, D. Jailard, and F. Crépel. 1994. Properties of glutamate receptors are modified during long-term depression in rat cerebellar Purkinje cells. Neurosci. Res. 19: 213-221.

Hofer, M., S.R. Pagliusi, A. Hohn, J. Leibrock, and Y.A. Barde. 1990. Regional distribution of brain-derived neurotrophic factor mRNA in the adult mouse brain. EMBO /. 9: 2459-2464.

Hyman, C., M. Hofer, Y.A. Barde, M. Juhasz, G.D. Yancopoulos, S.P. Squinto, and R.M. Lindsay. 1991. BDNF is a neurotrophic factor for dopaminergic neurons of the substantia nigra. Nature 350: 230-232.

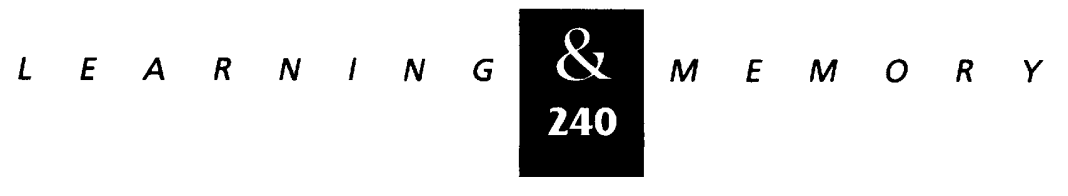


Isaacs, K.R., B.J. Anderson, A.A. Alcantara, J.E. Black, and W.T. Greenough. 1992. Exercise and the brain: Angiogenesis in the adult rat cerebellum after vigorous physical activity and motor skill learning. J. Cereb. Blood Flow Metab. 12: 110-119.

Isackson, P.J., M.H. Huntsman, K.D. Murray, and C.M. Gall. 1991. BDNF mRNA expression is increased in adult rat forebrain after limbic seizures: Temporal patterns of induction distinct from NGF. Neuron 6: 937-948.

Ito, M. 1984. The cerebellum and neural control. Raven Press, New York.

1989. Long-term depression. Annu. Rev. Neurosci. 12: $85-102$.

Ito, M. and L. Karachot. 1989. Long-term desensitization of quisqualate-specific glutamate receptors in Purkinje cells investigated with wedge recording from rat cerebellar slices. Neurosci. Res. 7: 168-171.

1990. Receptor subtypes involved in, and time course of, the long-term desensitization of glutamate receptors in cerebellar Purkinje cells. Neurosci. Res. 8: $303-307$.

1992. Protein kinases and phosphatase inhibitors mediating long-term desensitization of glutamate receptors in cerebellar Purkinje cells. Neurosci. Res. 14: 27-38.

Kalman, D., B. Wong, A.E. Horvai, M.J. Cline, and P.H. O'Lague. 1990. Nerve growth factor acts through cAMP-dependent protein kinase to increase the number of sodium channels in PC12 cells. Neuron 4: 355-366.

Kennedy, T.E., D. Kuhl, A. Barzilai, J.D. Sweat, and E.R. Kandel. 1992. Long-term sensitization in Aplysia leads to an increase in calreticulin, a major presynaptic calcium-binding protein. Neuron 9: 1013-1024.

Klein, R., D. Martin-Zanca, M. Barbacid, and L.F. Parada. 1990. Expression of the tyrosine kinase receptor gene trkB is confined to the murine embryonic and adult nervous system. Development 109: 845-850.

Knüsel, B., J.W. Winslow, A. Rosenthal, L.E. Burton, D.P. Seid, K. Nikolics, and F. Hefti. 1991. Promotion of central cholinergic and dopaminergic neuron differentiation by brain-derived neurotrophic factor but not neurotrophin-3. Proc. Natl. Acad. Sci. 88: 961-965.

Kokaia Z, J. Bengzon, M. Metsis, M. Kokaia, H. Persson, and $O$. Lindvall. 1993. Coexpression of neurotrophins and their receptors in neurons of the central nervous system. Proc. Natl. Acad. Sci. 90: 6711-6715.

Kokaia, Z., M. Metsis, M. Kokaia, J. Bengzon, E. Elmér, M.L. Smith, T. Timmusk, B.K. Siesjö, H. Persson, and O. Lindval. 1994. Brain insults in rats induce increased expression of the BDNF gene through differential use of multiple promoters. Eur. J. Neurosci. 6: 587-596.
Linden, D.J. and J.A. Connor. 1991. Participation of postsynaptic PKC in cerebellar long-term depression in culture. Science 254: 1656-1659.

Linden, D.J., M.H. Dickinson, M. Smeyne, and J.A. Connor. 1991. A long-term depression of AMPA currents in cultured cerebellar Purkinje neurons. Neuron 7: 81-89.

Lindvall, O., P. Ernfors, J. Bengzon, M.L. Smith, B.K. Siesjö, and $H$. Persson. 1992. Differential regulation of mRNAs for nerve growth factor, brain-derived neurotrophic factor, and neurotrophin 3 in the adult rat brain following cerebral ischemia and hypoglycemic coma. Proc. Natl. Acad. Sci. 89: 648-652.

Lu, B., M. Yokoyama, C. Dreyfus, and I.B. Black. 1991. Depolarizing stimuli regulate nerve growth factor gene expression in cultured hippocampal neurons. Proc. Natl. Acad. Sci. 88: 6289-6292.

Mayford, M., A. Barzilai, F. Keller, S. Schacher, and E.R. Kandel. 1992. Modulation of an NCAM-related adhesion molecule with long-term synaptic plasticity in Aplysia. Science 256: 638-644.

Mikoshiba, K., M. Huchet, and J.P. Changeux. 1979. Biochemical and immunological studies on the $P_{400}$ protein, a protein characteristic of the Purkinje cell from mouse and rat cerebellum. Dev. Neurosci. 2: 254-275.

Miranda R.C., F. Sohrabji, and C.D. Toran-Allerand. 1993 Neuronal colocalization of mRNAs for neurotrophins and their receptors in the developing central nervous system suggests a potential for autocrine interactions. Proc. Natl. Acad. Sci. 90: 6439-6443.

Montarolo, P.G., P. Goelet, V.F. Castellucci, J. Morgan, E.R Kandel, and S. Schacher. 1986. A critical period for macromolecular synthesis in long-term heterosynaptic facilitation in Aplysia. Science 234: 1249-1254.

Nawa, H., Y. Bessho, J. Carnahan, S. Nakanishi, and K. Mizuno. 1993. Regulation of neuropeptide expression in cultured cerebral cortical neurons by brain-derived neurotrophic factor. J. Neurochem. 60: 772-775.

Noonan, K.E., C. Beck, T.A. Holzmayer, J.E. Chin, J.S. Wunder, I.L. Andrulis, A.F. Gazdar, C.L. Willman, B. Griffith, D.D. Von Hoff, and I.B. Roninson. 1990. Quantitative analysis of MDR1 (multidrug resistance) gene expression in human tumors by polymerase chain reaction. Proc. Natl. Acad. Sci. 87: 7160-7164.

Otten, U., M. Goedert, N. Mayer, and F. Lembeck. 1980. Requirement of nerve growth factor for development of substance $P$-containing sensory neurons. Nature 287: 158-159.

Patterson, S.L., L.M. Grover, P.A. Schwartzkroin, and M. Bothwell. 1992. Neurotrophin expression in rat hippocampal slices: a stimulus paradigm inducing LTP in CA1 evokes increases in BDNF and NT-3 mRNAs. Neuron 9: 1081-1088. 


\section{Yuzaki et al.}

Rocamora, N., F.J. García-Ladona, J.M. Palacios, and G. Mengod. 1993. Differential expression of brain-derived neurotrophic factor, neurotrophin-3, and low-affinity nerve growth factor receptor during the postnatal development of the rat cerebellar system. Mol. Brain. Res. 17: 1-8.

Sellinger, O.Z., J. Legrand, J. Clos, and W.G. Ohlsson. 1974. Unequal patterns of development of succinate-dehydrogenase and acetylcholinesterase in Purkinje cell bodies and granule cells isolated in bulk from the cerebellar cortex of the immature rat. J. Neurochem. 23: $1137-1144$.

Stoppini, L., P.A. Buchs, and D. Muller. 1991. A simple method for organotypic cultures of nervous tissue. /. Neurosci. Methods 37: 173-182.

Tanabe, Y., M. Masu, T. Ishii, R. Shigemoto, and S. Nakanishi. 1992. A family of metabotropic glutamate receptors. Neuron 8: 169-179.

Teyler, T.J. and P. DiScenna. 1987. Long-term potentiation. Annu. Rev. Neurosci. 10: 131-161.

Timmusk, T., K. Palm, M. Metsis, T. Reintam, V. Paalme, M. Saarma, and H. Persson. 1993. Multiple promoters direct tissue-specific expression of the rat BDNF gene. Neuron 10: $475-489$.

Wisden, W., M.L. Errington, S. Williams, S.B. Dunnett, C. Waters, D. Hitchcock, G. Evan, T.V.P. Bliss, and S.P. Hunt. 1990. Differential expression of immediate early genes in the hippocampus and spinal cord. Neuron 4: 603-614.

Yuzaki, M. and K. Mikoshiba. 1992. Pharmacological and immunocytochemical characterization of metabotropic glutamate receptors in cultured Purkinje cells. /. Neurosci. 12: 4253-4263.

Zafra, F., B. Hengerer, J. Leibrock, H. Thoenen, and D. Lindholm. 1990. Activity dependent regulation of BDNF and NGF mRNAs in the rat hippocampus is mediated by non-NMDA glutamate receptors. EMBO f. 9: 3545-3550.

Zafra, F., D. Lindholm, E. Castrén, J. Hartikka, and H. Thoenen. 1992. Regulation of brain-derived neurotrophic factor and nerve growth factor mRNA in primary cultures of hippocampal neurons and astrocytes. J. Neurosci.

12: 4793-4799.

Received August 15, 1994; accepted in revised form November 9, 1994. 


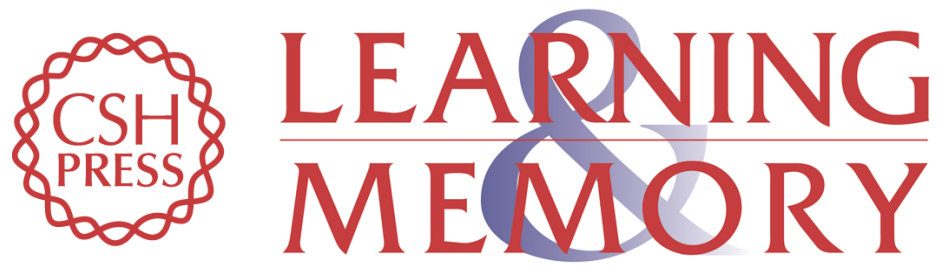

\section{A stimulus paradigm inducing long-term desensitization of AMPA receptors evokes a specific increase in BDNF mRNA in cerebellar slices.}

M Yuzaki, T Furuichi, K Mikoshiba, et al.

Learn. Mem. 1994, 1:

Access the most recent version at doi:10.1101//m.1.4.230

References This article cites 52 articles, 16 of which can be accessed free at:

http://learnmem.cshlp.org/content/1/4/230.full.html\#ref-list-1

License

Email Alerting

Service

Receive free email alerts when new articles cite this article - sign up in the box at the top right corner of the article or click here. 